\title{
Whistleblowing System in Indonesia's Directorate General of Tax
}

\author{
Ditri Andita Anggariani (Author) \\ Faculty of Administrative Science \\ University of Indonesia \\ Depok, Indonesia \\ Ditri.andita@yahoo.com
}

\author{
Teguh Kurniawan (Author) \\ Faculty of Administrative Science \\ University of Indonesia \\ Depok, Indonesia \\ Teguh.kurniawan@ui.ac.id
}

\author{
Defny Holidin (Author) \\ Faculty of Administrative Science \\ University of Indonesia \\ Depok, Indonesia \\ defny@ui.ac.id
}

\begin{abstract}
Despite the nature of public organizations that have a control mechanism, illegal practices often occur in public sectors due to the lack of control. Indonesia's Directorate General of Tax is implementing a whistleblowing system to detect illegal practices in its institution. This research describes the relation between the whistleblowing system and the Government's Internal Control System in the directorate to improve internal control. After analyzing data from in-depth interviews, studies of related published documents, and observations, results suggest that reform in the whistleblowing system does not only serve as a tool to improve internal control; it is also a part of the control itself. However, the positioning of units in charge of the whistleblowing system needs to be reviewed. Moreover, supporting facilities for whistleblowers need improvement.
\end{abstract}

Keywords—whistleblowing system; internal control; Directorate General of Tax; Indonesia.

\section{INTRODUCTION}

As tax administrator, the Directorate General of Tax (DGT) plays a crucial role in Indonesia's government. Paying tax is similar to investing through the government; our collected money will be given back to us as public goods and public services. Indonesia's National Budget data shows that tax money dominates Indonesia's domestic income (Budget Statistics, Ministry of Finance, 2013). Tax income in 2013 even reached around $80 \%$ of Indonesia's total domestic income, making it the main income generator for the Indonesian government.

The tax revenue target for 2013 to 2014 is aimed at around 1000 trillion Rupiah (Rp) (Bisnis Indonesia, 2013). According to Patrialis Akbar (former Indonesian Constitutional Court Judge), that target will be easily achieved if every DGT official has integrity (Metro TV News, 2013). Thus, it is important for human resources in DGT to have integrity, not just competence or skills. Singh and Sachdeva stated that administrative leadership is the most effective internal control system: "If the top managers are honest and incorruptible, the subordinates would usually not dare to resort to corruption, negligence, etc" (Singh and Sachdeva, 2012, p. 229). The hierarchal nature of public-sector administration automatically forms an internal control system, where supervisors watch over their subordinates' acts (Singh and Sachdeva, 2012).
Past corruption scandals involving DGT officials show that top managers do not always play their role as internal controllers as explained by Singh and Sachdeva (2012). Take Hadi Poernomo's case as an example. Poernomo, who held the position of Director of DGT in 2001-2006, was suspected of manipulating the decision on taxpayer's objection petition of Bank Central Asia in 2004 (Republika Online, 2014). His position as echelon I in DGT at that time proved that illicit behaviors could occur even among top-level officials. Poernomo's disgraceful act has just been uncovered recently, ten years after the event took place. The ten-year interval between the event and the handling of Poernomo's case is a sign of the weak internal control in DGT.

As an effort to improve internal control, DGT (alongside with the Ministry of Finance) has implemented the Whistleblowing System (WBS), which is defined as follow: "... an accepted and protected process of informing superiors of any immoral and dangerous action that is taking place" (Kiran, 2007, p. 136). The Whistleblowing System itself is derived from the 'whistleblowing' concept, which literally means 'blowing the whistle'. According to Johnson "since the early 1970s, whistleblowing has become a common means of describing dissent in a bureaucracy, particularly when issues of public health, safety, fraud, or abuse of office are involved" (Johnson, 2003, p. 4). According to Hadi (2012) in DGT's official website, the whistleblowing system in DGT is based on three principles: prevention, early detection, and effective countermeasure. The Directorate of Internal Compliance and Apparatus Transform (Directorate ICAT) is a DGT unit, which helps echelon one in internal control activities throughout DGT. The public can also file a complaint to DGT using either the online or offline system.

Government regulation Number 60 of 2008 about the Government's Internal Control System appoints the Inspectorate General as the Government's Internal Controller (GIC) at Ministrial level. GIC is a unit in the Central Government, Regional Government, State Ministry, Government Agencies and Non-Department Government Agencies, which has control functions within its authority (Inspectorate General of Ministry of Finance, n.d., p. 5). GIC's activities are not only limited to financial control activities, but also include the preservation of integrity, giving consultation to units within the ministry, and so on. As GIC, the Inspectorate 
General of the Ministry of Finance has an obligation to provide early warning indications of violations in the environment, as stated in Government Regulation Number 60 of 2008. The Inspectorate General in the Ministry of Finance is divided into eight units, each overseeing echelon one units within the Ministry of Finance with Inspectorate I overseeing DGT. The Inspectorate General of the Ministry of Finance has also implemented a whistleblowing system that is managed by the Inspectorate Division of Investigation (IDI). Complaints to the Inspectorate General can be made online or offline.

Nevertheless, WBS implementation is not dilemma-free. Whistleblowers are susceptible to the notion that they are "a lowlife who betrays a sacred trust largely for personal gain" (Miethe, 1999, p. 12). Speaking of its implementation in DGT, the Board of Nahdlatul Ulama (one of Indonesia's prominent religious organizations), $\mathrm{KH}$ Malik Madani reminded that WBS could cause internal disharmony among Tax officials (Republika Online, 2012). The disharmony could arise from the feeling of being 'spied on' by their colleagues. Economist Jose Rizal offered his own view: "This system may be effective in capturing corrupt employees. However, it can also be used as a weapon to bring down fellow employees. DGT should be aware and have concern for this" (Kontan, 2013). The existence of the Directorate ICAT and the Inspectorate General as whistleblowing system administrators with different complaint channels requires good coordination between the two. Handling the sensitive and complex WBS requires careful cooperation of all parties involved.

Structurally, the Inspectorate General is one level above the Directorate ICAT. Therefore, in some aspects internal control activities in DGT involve the Inspectorate General, including the management of the whistleblowing system. Considering the function of internal control, assisted by the whistleblowing system as a management tool in DGT and the Inspectorate General's intervention in the management of DGT's WBS, this research resulted in the question "how is the mechanism of the relationship between the WBS and the Government's Internal Control System in the DGT in improving internal control?"

\section{THEORETICAL FRAMEWORK}

Accountability and control are intertwined, inseparable mechanisms. As Goldring and Wettenham (1980) argued: "The answerability mechanism provides information to the controller, and may indicate the occasions on which the control mechanism is to be brought into play" (quoted by Stenning, 1995, p. 51). Control mechanism may arise from external or internal sources; Jensen (1993) proposed that if external control mechanisms weaken and fail to respond, internal control will be the only remaining option to secure an organization's assets (Waymire, 2008).

Internal control is developed from "policies and procedures designed to provide management with reasonable assurance that the company achieves its objectives and goals" (Arens, Elder, Beasley, 2006, h. 270). The components of internal control according to COSO's Internal Control - Integrated Framework as the most widely-used framework for internal control, cover a) control environment, b) risk assessment, c) control activities, d) information and communication, d) monitoring (Arens, Elder and Beasley, 2006, p. 274). The existence of internal control does not seem to guarantee the achievement of organizational goals because environmental factors and procedural matters affect internal control.

The responsibility for internal control is divided into several groups: the governing body, the management, each person within the organization, staff in support functions or external experts, both internal and external assurance providers (IFAC, 2012). The governing body is in charge of the whole process of internal control, whereas internal and external assurance providers are responsible to monitor and evaluate the effectiveness of internal control in order to assure the governing body. Given the variety of actors involved in internal control, coordination among them is mandatory (IFAC, 2012). The implicit nature of coordination often causes it to fail due to multiple interpretations that may occur among actors involved (Bouckaert, Peters, and Verhoest, 2010).

An effective internal control system requires control from every level in the organization. A complaint mechanism that serves as a tool for everyone in the organization to file a complaint is essential for an organization's internal control, as expressed by OECD (2011): “An important issue in corporate internal control is the possibility for stakeholders to file a complaint with competent institutions within the company regarding illegal or unethical practices existing therein" (h. 103). The Association of Certified Fraud Examiners' research shows that WBS is the least practiced anti-fraud mechanism, despite its effectiveness in detecting fraud losses (Olsen, 2010). In its development, it also provides a way for external parties to report frauds within an organization.

\section{MethodOLOGY}

Data in this research has been acquired using qualitative techniques with in-depth interviews, documentary methods, and site observation. Interviews were conducted with related parties, as shown in the table below:

TABLE I. INFORMANT LIST

\begin{tabular}{|c|c|}
\hline Institution & Position \\
\hline Directorate ICAT, DGT & $\begin{array}{l}\text { Internal Investigation Section II } \\
\text { Implementer }\end{array}$ \\
\hline $\begin{array}{l}\text { IDI, Inspectorate General of Ministry } \\
\text { of Finance }\end{array}$ & First Auditor \\
\hline $\begin{array}{l}\text { Inspectorate } 1, \quad \text { Inspectorate } \\
\text { General of Ministry of Finance }\end{array}$ & $\begin{array}{l}\text { Head of Sub Division of } \\
\text { Administration }\end{array}$ \\
\hline $\begin{array}{ll}\text { Corruption } & \text { Eradication } \\
\text { Commission (CEC) } & \end{array}$ & Public Complaints Functional \\
\hline $\begin{array}{l}\text { Finance and Development } \\
\text { Monitoring Body }\end{array}$ & $\begin{array}{l}\text { Head of Investigation Team } \\
\text { Investigation Technical Controller }\end{array}$ \\
\hline Kemitraan Partnership & Integrity Expert \\
\hline $\begin{array}{l}\text { Faculty of Economics, Universitas } \\
\text { Indonesia }\end{array}$ & $\begin{array}{l}\text { Lecturer at Faculty of Economics, } \\
\text { Universitas Indonesia }\end{array}$ \\
\hline
\end{tabular}


Interviewees from government bodies were appointed by their organizations upon the researchers' request. The researchers selected expert and lecturer interviewees based on their knowledge about internal control and the whistleblowing system.

The documentary method research was used to collect data from the government's official documents about internal control and WBS, particularly those published by the Ministry of Finance and the DGT. The researchers also reviewed books, online magazines, newspapers, and journals related to whistleblowing systems and internal control, both in the Ministry of Finance and in the DGT. Observation carried out during the research process was unplanned at first. As the researchers visited each government official interviewee, observation on whistleblowing supporting facilities was done incidentally. All data was then compiled and retold as a narration that described the relationship of the whistleblowing system and the government's internal control system in the DGT.

\section{FINDINGS AND DISCUSSIONS}

\section{A. Relationship of the whistleblowing system and the Government's Internal Control System}

The five pillars of COSO's internal control as set out in Government Regulation number 60 of 2008 on the Government's Internal Control System appointed the Inspectorate General as the functional of internal control activities in a ministry. In short, the Inspectorate General is responsible for, at least, quality assurance, giving early warning signs, and consultation. Inspectorate 1 is a unit in the Inspectorate General of the Ministry of Finance, which oversees the DGT. Inspectorate 1 is more involved in preventing violations through quality assurance and consultation. As for monitoring activities, Inspectorate 1 is only involved when needed. Monitoring activities are the basis for the GIC in recognizing risks, which enriches GIC's knowledge when giving consultation.

When violations of regulations continue to occur when preventive measures have been taken, then an organization requires a means to dismantle the offense. Complaint channels open opportunities of information so that information regarding violations of regulations can enter not only from internal but also from external parties. The whistleblowing system is a complaint channel used alongside with the implementation of internal controls. As the GIC, the Inspectorate General manages complaint channels under the IDI. The DGT itself also manages complaint channels that apply in its organization. The Directorate ICAT is a unit of the DGT, engaged in internal compliance, including the handling of complaints related to code of conduct and discipline.

Complaint channels for internal monitoring of activities in the DGT focuses on the correction for improving organizational performance directly, while complaint channel to the Inspector General serve as the 'eyes and ears' when implementing internal controls. That difference resulted in the division of tasks between Directorate ICAT and IDI regarding the follow-up of complaints. Thus, the establishment of an integrated pattern of complaint follow-up between the Directorate ICAT and IDI is crucial, so that no information $\mathrm{g}$ goes missing or is overlapping.

Integration starts with dividing authority in dealing with complaints in the WBS. Complaints are divided into three types: breach of ethics, public relations and/or services, and complaints involving taxpayers. Ethical violations are divided into two: one is the indication of fraud and another is the abuse of authority. The Investigation Inspectorate will follow its own complaints concerning violations of ethics that goes through the Inspector General complaint channels, while complaints related to public relations and/or services as well as taxpayers will be transferred directly to the DGT. Violations concerning ethics are divided into violations regarding duties and functions and violations not related to duties and functions. Violations that are not related to duties and functions are divorce and employees' personal affairs, to name a few. These types of offense will also be transferred to the Directorate ICAT when received from Inspectorate Investigation's whistleblowing channel.

Receiving complaints first-hand has enabled the Directorate ICAT to correct their wrongs in a more timely manner. They do not need to wait for official reports from other parties to acknowledge their management deficiencies. However, the Directorate ICAT exercises limited authority in following up on complaints. The Directorate ICAT's position as echelon II makes this directorate have limitations on following up information from the whistleblowing system in the framework of internal control. They do not always handle complaints that go through the Directorate ICAT's whistleblowing channel independently. Cases involving officials at a certain level will involve the Investigation Inspectorate.

The Inspector General manages the submission of information regarding the tax authorities to external law enforcement such as the CEC and the CEC will only act only after an official report is received. Given that the Inspector General is the only authority in the delivery of information to external parties, then this research sees a gap that can be exploited to manipulate the handling of complaints. The Directorate ICAT does not have the authority to disclose information to external parties if the Inspector General decides not to forward the information.

The management of complaints channel activities exercised by the Directorate ICAT and the Investigation Inspectorate is supported by the integration of applications used in receiving complaints. Do note that the current Whistleblowing System application (WiSe) managed by the Investigation Inspectorate has been integrated with the Tax Complaint Information System (TCIS) managed by the DGT, so the reports coming through TCIS will automatically be recorded in WiSe (but not vice versa). As a coordinator, the Investigation Inspectorate will receive periodic reports on the handling of the whistleblowing system managed by the Directorate ICAT. Reports to the Investigation Inspectorate containing the status of cases handled by the Directorate ICAT are submitted every three months. For cases that were originally reported to the Inspectorate but then transferred to the Directorate ICAT, the Inspectorate would require more detailed reports. The 
integration of WISE application with TCIS allows the Investigation Inspectorate to monitor the Directorate ICAT's whistleblowing activities without having to wait for an official report.

Coordination between the Inspectorate Investigation and the Inspectorate Investigation 1 (the division that is responsible for the quality assurance and consultation function of the DGT) is formed when needed, as there are certain occasions in which the Investigation Inspectorate 1 needs help from Inspectorate 1 during the investigation of a case. In addition, there is also regular coordination in the form of regular meetings. Whistleblowing systems can reinforce GIC roles in assurance and consulting activities. Even though the whistleblowing system is in Investigation Inspectorate's domain, this research suggests that the involvement of Inspectorate 1 is lacking in the whistleblowing system. As the division that performs quality assurance and consulting functions for the DGT, Inspectorate 1 should receive a holistic and more up-to-date report of all whistleblowing activities related to the DGT, not only through the Inspectorate General's regular meetings. A fluent exchange of information regarding the tax authorities between these two units of the Inspectorate General (Inspectorate Investigation and Inspectorate 1) can minimize the possibility of missed information and redundancy when coordination is only formed when deemed necessary.

The internal control process undertaken by the Inspectorate General consists of a series of procedures to develop an internal control system. A group of internal control procedures forms a design of preventive surveillance. As a preventive process, the purpose of the internal control system is to minimize leaks that occur in an organization, not to absolutely eliminate leaks. Lack of integrity and competency of some of parties may raise the risk of leakages in the implementation of internal control. The whistleblowing system in the DGT is a tool used by the internal control's actors to detect violations that occur in the organization regardless of the internal control system that has been implemented, so it can be regarded as a detective control. Tax authorities will use information from WBS to improve its organization. The whistleblowing system in the DGT indicates that detective controls will lead to corrective control.

Considering the whistleblowing system implemented in the DGT and its relation with government internal control systems, this research notes a variance in DGT's whistleblowing system compared to whistleblowing systems in general. Generally, the whistleblowing system in an organization is only handled by one specific internal unit. However, DGT's whistleblowing system involves two separate units with an intersecting function: the Inspectorate General (IDI in particular) and the Directorate ICAT. Given that the Inspector General acts as the coordinator of the whistleblowing system under the government's internal control system, the Directorate ICAT needs an approval from the coordinator before involving external law enforcement in a case. This might indicate an opportunity to manipulate the information disclosure, especially in high-profile cases.

This research has found that the process for handling incoming information through the whistleblowing system in the DGT has not fully ensured the accountability of complaints handling, considering the limited involvement of the external law enforcements in the implementation of the whistleblowing systems in the DGT. The case involving Poernomo (Republika Online, 2014) is a proof that violations can actually come from the highest level within the organization. Given this fact, the authority to pass information to external law enforcement (CEC, the police, or prosecutors) should not be monopolized by one single unit (the Inspectorate General).

\section{B. WBS in improving internal control in the DGT}

WBS initially raised pros and cons in the DGT as fears and suspicion appeared among colleagues. The Director General of Tax regulation No Per-22 / PJ / 2011, article 19 on Reporting Obligations and Handling Violations Reporting Violations (Whistleblowing) in the DGT stipulates that employees who are proved to have submitted false/defamatory complaints will be penalized in accordance with the regulations. The article does not regulate false complaints/slanders made by parties other than employees, but it shows goodwill at the very least from the DGT to protect their employees from false accusations. Negative opinions of the whistleblowing system are decreasing; cons still rise from some employees, though, especially those who are used to committing violations in their work. The DGT and the Ministry of Finance have set up regulations related to the whistleblowing system, but the law in Indonesia has yet to establish appropriate protection for whistleblowers (Boas, 2008). Based on this, the function of the Witness and Victim Protection Agency has not led to the protection of whistleblowers, due to the different characteristics of 'a witness' and 'a whistleblower'. Moreover, there is still no organization for whistleblowers to turn to for a mental support. An example of this is Australia with Whistleblowers Australia that serves as a support group for whistleblowers.

WBS's improvement through regulations is also strengthened by the use of technology in providing complaint channels. Both the Investigation Inspectorate and the DGT manage their own complaint applications, adding variations to existing complaint channels. The main advantage of an online WBS is anonymity. The online system allows the complainant to use a pseudonym and minimize direct contact with report recipients, therefore, identity is protected. The Directorate ICAT provides a help desk where a complainant can come directly to make a complaint. Currently, the help desk is located on the 20th floor of the DGT building, inside the Directorate ICAT's office space. The positioning of the help desk may suppress the interest of the public who wish to report directly due to anonymity issues as entering the DGT building requires visitors to leave their IDs at the lobby and state their purpose of visit. Moreover, a complainant must pass through the Directorate ICAT's employee workspace to reach the help desk. These procedures increase the possibility of DGT's employees (apart from complaint help desk's officer) to know/recognize the identity of a complainant.

The Investigation Inspectorate party has begun advising those who wish to make a complaint to use the complaint app that has been provided because the online system cuts the bureaucracy of communication, thus resulting in quicker 
responses. On the other hand, the Directorate ICAT does not have a particular preference regarding which complaint channel is to be used by whistleblowers. The Directorate ICAT's staff will receive a complaint form completed by the channel's administrator. Therefore, all reports received by the managers in the Directorate ICAT would be in the same form regardless of the channel selected when making a complaint. This research observed that the whistleblowing site is the most effective and efficient way in making a complaint in terms of procedures and completeness of the information, so far.

The existence of an online-based whistleblowing channel not only complements the internal control system implemented in the DGT, but also improves it. Before the era of online-based whistleblowing systems, incoming complaints were recorded manually. Documenting manually caused old data not to be well-documented and difficult to trace. This difficulty was admitted by the Inspectorate of Investigation when asked for pre-2011 complaints data to be used as secondary data in this research. They were only able to give data that had been recorded in the online whistleblowing system. Now online applications of WiSe and TCIS are also used as a database for incoming complaints, including complaints from non-online channels.

As the implementers of internal control in the DGT, the Directorate ICAT admitted it is helped by the fact that the complaints system has been strengthened through agency regulations and technology sophistication. It is now easier for the head of executors to monitor the work progress of his division because there is now a clear-cut division of tasks so it is clear who handles what, thanks to clear-cut complaints handling procedures. In addition, the integration between WiSe and TCIS facilitate a quicker exchange of information between the Directorate ICAT and Inspectorate Investigation.

Since the management of complaints has been revamped through regulations and strengthened by the use of technology, the number of complaints concerning the DGT received by the Directorate ICAT and IDI has shown an increasing trend from year to year, as seen in tables below:

TABLE II. COMPLAINTS RECEIVED BY DIRECTORATE ICAT

\begin{tabular}{|c|c|c|c|}
\hline Year & $\mathbf{2 0 1 1}$ & $\mathbf{2 0 1 2}$ & $\mathbf{2 0 1 3}$ \\
\hline $\begin{array}{c}\text { Complaints } \\
\text { received }\end{array}$ & 123 & 201 & 272 \\
\hline \multicolumn{4}{|c|}{ *Source: Researcher (From Annual Report of DGT, 2013). } \\
\hline
\end{tabular}

TABLE III. COMPLAINTS REGARDING DGT RECEIVED BY IDI

\begin{tabular}{|c|c|c|c|c|c|c|c|}
\hline \multicolumn{2}{|c|}{2011} & \multicolumn{2}{|c|}{2012} & \multicolumn{2}{|c|}{2013} & \multicolumn{2}{|c|}{$\begin{array}{l}2014 \text { (until } \\
\text { February) }\end{array}$} \\
\hline $\begin{array}{l}\text { Fra } \\
\text { ud }\end{array}$ & $\begin{array}{c}\text { Non } \\
\text { Fraud }\end{array}$ & $\begin{array}{c}\text { Frau } \\
\text { d }\end{array}$ & $\begin{array}{c}\text { Non } \\
\text { Fraud }\end{array}$ & Fraud & $\begin{array}{c}\text { Non } \\
\text { Fraud }\end{array}$ & $\begin{array}{c}\text { Frau } \\
\text { d }\end{array}$ & $\begin{array}{c}\text { Non } \\
\text { Frau } \\
\text { d }\end{array}$ \\
\hline 4 & 10 & 48 & 135 & 109 & 174 & 10 & 11 \\
\hline \multicolumn{2}{|c|}{$\Sigma 14$} & \multicolumn{2}{|c|}{$\Sigma 183$} & \multicolumn{2}{|c|}{$\Sigma 283$} & \multicolumn{2}{|c|}{$\Sigma 21$} \\
\hline
\end{tabular}

This increase in complaints can be viewed from two perspectives. The first viewpoint indicates that from year to year the number of violations increases. The second viewpoint suggests the possibility that in fact there are many cases of violations, yet from year to year more and more parties are encouraged to make a complaint. One certain matter that can be concluded from those two possibilities is that along with the increasing familiarity of whistleblowing among employees and public each year, more and more parties are encouraged to assist in the implementation of internal control in the DGT by reporting indications of violations.

Despite the excellence of the online whistleblowing channel, this system is not automatically the most preferred method to file a complaint. Post mail is still the most widely used complaint channel, mainly because the users are more familiar with it. Submitting a complaint through a website requires access to the Internet (this relates to the ability to access and the availability of access itself), whereas the Marketing Director of Telkomsel stated that $73 \%$ of Indonesia's population is internet-blind (Detik Inet, 2014), and furthermore, access to the Internet is still concentrated in large cities. Another weakness of the online complaint channel is that this channel is still not integrated across-agencies. Currently the online complaint channel to report tax employees is only integrated across internal divisions in the DGT (between WiSe and TCIS).

The existence of different complaint channels with different administrators allows complainants to choose which channel to use when making a complaint. The administrators in the Directorate ICAT and the IDI will then sort out which complaints fall under which domains (Directorate ICAT's or IDI's). Integration between WiSe and TCIS does facilitate the administrators in exchanging information, but the complainants often do not know that the information has been passed on to another unit. This may cause a problem when the complainants ask about the progress of their report to the unit that initially received the report, and the said unit does not know the recent update of the case, given that WiSe and TCIS integration only allows for short information exchanges. This difficulty can be minimized if the Directorate ICAT and the IDI each appoint a person in charge that are in direct contact regarding information exchange.

The implementation of WBS in the DGT basically has three objectives: prevention, coping with, and providing a deterrent effect. Both the Directorate ICAT and Inspectorate of Investigation admit that for now those three objectives have not been fully achieved. Currently WBS has only covered the second objective (coping). This study observed that until now WBS is mainly used as a response tool to complaints rather than a prevention tool. As for the third objective, researchers regard it as an additional effect of the presence of the whistleblowing system. The prevention function is perceived as an additional effect because WBS works like a Closed-Circuit Television (CCTV) in the workspace. In addition, it is the Inspectorate General's responsibility as GIC to close loopholes that allow violation (prevention).

Regardless of the increasing quality of internal control due to procedural factors, environmental factors such as the competence and integrity of the executives and employees play a major role in improving the quality of internal control. The Directorate ICAT collaborates with external parties such as 
donors, CEC and the Audit Board of the Republic of Indonesia in improving internal control staff competence through training. In their effort to enhance staff's integrity, the DGT holds routine activities such as gatherings and in-house training to internalize the Ministry of Finance's values.

General public may also submit complaints to DGT's WBS, thus, helping to improve the internal control. Therefore, this study noted that the Directorate ICAT should pay more attention to their approaches to the public, for example through socialization that educates and fosters public trust and awareness to use WBS. No socialization materials can be seen from outside as well as inside the building complex of the DGT's Central Office and the Ministry of Finance buildings. Informants from the IDI stated that their current socialization targets are the employees of the Ministry of Finance, which explains why they only put socialization materials inside office buildings. However, putting up socialization materials in front of the office buildings will be able to reach not only the employees (who are the current target) but also the general public.

\section{CONCLUSION}

Based on the analysis above, this research resulted in the following points:

- As the coordinator of WBS, the Inspector General is the sole party that may disclose information to external law enforcements. This may weaken the internal control system in DGT since the Directorate ICAT as an executor at the directorate level holds no authority to carry a further investigation of a case with external law enforcements without the Inspector General's consent.

- Despite the improvement of procedures and systems that have been carried out by the DGT, external factors are not yet conducive to give protection to whistleblowers. This is evident from the weak position of whistleblowers in the eyes of law and the absence of a support group for whistleblowers.

- Integrity and competence are also determinants of the quality of internal controls, in addition to improved procedural factors such as a whistleblowing system that has been conducted in the DGT.

Based on the research that has been done, this study suggests that:

- Inspectorate 1 should be more involved in the implementation of the whistleblowing systems to improve quality assurance and consulting activities, by for example providing periodic reports on the implementation of the whistleblowing systems in the DGT.

- The Ministry of Finance should establish a unit/a new team responsible for the whistleblowing system that consists of representatives of the Inspector General and the Directorate ICAT (as well as other similar directorates in the Ministry of Finance), which are directly responsible to the head of the institution. Investigation of a case may be handed over to relevant compliance units in each directorate general, but all members of the new unit/team should have the same authority in making decisions on the results of investigations that have been conducted, including on the forwarding of information to the external law enforcements.

- The DGT should begin to integrate their WBS application with similar applications used in other government agencies, such as CEC, the State Ministry for the Empowerment of State Apparatus and Bureaucratic Reform, and the National Police in order to make sure that no information is being held back from external parties. Complainants may choose the agencies they wish to tag in their complaints and a report will automatically be forwarded to those agencies. In addition, a separate help desk accessible to the general public should be provided.

\section{REFERENCES}

[1] Ministry of Finance, (2013), Budget Statistics 2007-2013.

[2] Bisnis Indonesia, 'Pemerintah Koreksi Target Penerimaan Pajak 2014', (Online) at http://finansial.bisnis.com/read/20130926/10/165561/targetpenerimaan-pajak-2014-dikoreksi-jadi-rp10341-triliun, accessed November $16^{\text {th }}, 2013$.

[3] Metro TV News, 'Target Pajak Rp1000 Triliun Mudah Tercapai Jika', (Online) http://www.metrotvnews.com/metronews/read/2013/06/07/2/159723/Tar get-Pajak-Rp1000-Triliun-Mudah-Tercapai-Jika, accessed November $18^{\text {th }}, 2013$.

[4] Singh, H., \& Sachdeva, P. (2012). Public Administration: Theory and Practice, New Delhi: Pearson Education India.

[5] Republika Online. (2014). Begini Kronologi Kasus Korupsi Hadi Poernomo. (Online) at http://www.republika.co.id/berita/nasional/hukum/14/04/22/n4dv9bbegini-kronologi-kasus-korupsi-hadi-poernomo, accessed May $2^{\text {nd }}$, 2014.

[6] Kiran, D. R. (2007). Professional Ethics and Human Values, New Delhi: Tata McGraw-Hill.

[7] Johnson, R. A. (2003). Whistleblowing: When It Works -And Why, UK: Lynne Rienner Publisher.

[8] Hadi, W. (2012). Mengintip Whistleblowing System dan Gerakan AntiKorupsi di Pajak. (Online) at http://www.pajak.go.id/content/article/mengintip-whistleblowingsystem-dan-gerakan-anti-korupsi-di-pajak, accessed November $16^{\text {th }}$, 2013.

[9] Peraturan Pemerintah Republik Indonesia Nomor 60 Tahun 2008 tentang Sistem Pengendalian Internal Pemerintah (Government Regulation number 60/2008 about Government's Internal Control System).

[10] Inspectorate General of Ministry of Finance. (n.d.). Frequently Asked Questions. (Online) http://www.itjen.kemenkeu.go.id/files/kontak/FAQ\%20Itjen.pdf, accessed November $16^{\text {th }}, 2013$.

[11] Miethe, T. D. (1999). Whistleblowing at Work: Tough Choices in Exposing Fraud, Waste, and Abuse on the Job, Colorado: Westview Press.

[12] Republika Online. (2012). KH Malik Madani: Whistleblowing System Tingkatkan Profesionalitas. (Online) at http://www.republika.co.id/berita/nasional/umum/12/08/15/m8sflz-khmalik-madani-whistleblowing-tingkatkan-profesionalitas, accessed November $20^{\text {th }}, 2013$.

[13] Kontan. (2013). Jose Rizal: Dengan Whistleblowing System Pajak Lebih Bersih dari Korupsi. (Online) at http://klien.kontan.co.id/advertorial/client/pajak/69/Jose-Rizal-DenganWhistleblowing-System-Pajak-Lebih-Bersih-dari-Korupsi, accessed November $15^{\text {th }}, 2013$.

[14] Stenning, P. C. (1995). Accountability in the Ministry of the Solicitor General of Canada. In P. C. Stenning, Accountability for Criminal Justice: Selected Essays (p. 44). Toronto: University of Toronto Press. 
[15] Arens, A. A., Elder, R. J., \& Beasley, M. S. (2006). Auditing and Assurance Services: An Integrated Approach (Vol. 11th), New Jersey: Pearson Prentice Hall.

[16] Waymire, T. R. (2008). Internal and External Control Mechanisms: The Impact of Alignment on Market and Operating Performance. University of Arkansas.

[17] IFAC. (2012). Evaluating and Improving Internal Control in Organizations. Professional Accountants in Business Committee International Good Practice Guidance: Final Pronouncement.

[18] Bouckaert, G., Peters, B. G., \& Verhoest, K. (2007). Reforms of Central Government Coordination in OECD Countries: Culture as Counterforce for Cross-national Unifying Processes? . Amsterdam: Elsevier.

[19] OECD. (2011). Corporate Governance of Listed Companies in China Self-Assessment by the China Securities Regulatory Commission: Self-
Assessment by the China Securities Regulatory Commission. OECD Publishing.

[20] Olsen, W. P. (2010). The Anti-Corruption Handbook: How to Protect Your Business in the Global Marketplace, New Jersey: John Wiley \& Sons.

[21] Boas, F. (2008). Perlindungan Terhadap Whistleblower dalam Rangka Perlindungan Saksi dan Korban di Indonesia, Universitas Indonesia.

[22] Directorate General of Tax. (2013). Annual Report.

[23] Inspectorate Division Investigation of Ministry of Finance . (2014). Data on Whistleblowing System (Confidential).

[24] Detik Inet. (2014). 73\% Masyarakat Indonesia Buta Internet. (Online) at http://inet.detik.com/read/2014/03/24/154003/2534887/328/73masyarakat-indonesia-buta-internet, accessed April 20 ${ }^{\text {th }}, 2014$. 